\title{
IL17F wt Allele
}

National Cancer Institute

\section{Source}

National Cancer Institute. IL17F wt Allele. NCI Thesaurus. Code C114482.

Human IL17F wild-type allele is located in the vicinity of $6 \mathrm{p} 12$ and is approximately $8 \mathrm{~kb}$ in length. This allele, which encodes interleukin-17F protein, is involved in cytokine production, cartilage turnover and the regulation of angiogenesis. Mutation of the gene is associated with familial Candidiasis type 6. 